\title{
An Evaluation of Cucurbits for Susceptibility to Cucurbitaceous and Solanaceous Phytophthora capsici isolates
}

T. B. Enzenbacher, Former Graduate Research Assistant, and M. K. Hausbeck, Professor, Department of Plant Pathology, Michigan State University 48824

\begin{abstract}
Enzenbacher, T. B., and Hausbeck, M. K. 2012. An evaluation of cucurbits for susceptibility to cucurbitaceous and solanaceous Phytophthora capsici isolates. Plant Dis. 96:1404-1414.

Cucumber (Cucumis sativus) and squash (Cucurbita spp.) production in Michigan is limited by the oomycete pathogen Phytophthora capsici. Cucumber, summer squash, and winter squash fruit were evaluated for susceptibility to five isolates of $P$. capsici. Detached fruit were inoculated with a 5-mm-diameter culture plug of mycelia and sporangia and were incubated in a laboratory or greenhouse. Lesion and pathogen growth diameters were measured and pathogen growth density was visually assessed. All $P$. capsici isolates incited rot, with significant differences found among fruit type and pathogen isolate. Straightneck squash (Cucurbita pepo), slicing cucumber, and butternut

fruit tested. Summer and winter squash seedlings were evaluated in greenhouse experiments, in which $P$. capsici-infested millet seed (approximately $1 \mathrm{~g}$ ) were placed on the surface of soilless potting media. Disease severity was visually assessed every 2 days for 14 days post inoculation. Crop type, pathogen isolate, or the crop type-pathogen isolate interaction term were significant for symptom appearance and area under the disease progress curve values. Differences in susceptibility of butternut squash and zucchini cultivars were observed following inoculation with solanaceous isolate 13351. Results from this study can refine management programs for Phytophthora rot.
\end{abstract} squash (C. moschata) exhibited more severe symptoms than the other
Phytophthora capsici Leonian, an oomycete plant pathogen, is a yearly threat to the Michigan vegetable industry. $P$. capsici was first found to be the causal agent of chili pepper (Capsicum annuum L.) foliar blight in New Mexico in 1918 (27), and now has been reported to cause disease on over 50 plant genera (13). Vegetable crops that are susceptible to $P$. capsici include those in the Cucurbitaceae, Fabaceae, and Solanaceae families, and include cucumber (Cucumis sativus L.), melon (C. melo L.), pumpkin ( $\mathrm{Cu}$ curbita pepo L.), summer and winter squash (Cucurbita spp.), lima and snap bean (Phaseolus spp.), bell pepper (Capsicum annuum), tomato (Solanum lycopersicon L.), and eggplant (S. melongena L.) $(7,9,10,12,16,23,24,49)$. Michigan is ranked among the top 10 states in the United States for the production of many of these crops, specifically bell pepper, cucumber, snap bean (Phaseolus vulgaris L.), squash, and tomato, with a value of $\$ 137$ million in 2010 (50). In 2010, Michigan was ranked number one for the production of pickling cucumber and the combination of processing and fresh market squash, with $\$ 61.7$ million in value and 15,216 harvested ha (50).

Cucurbits and pepper are considered to be the most vulnerable hosts of Phytophthora capsici $(2,48)$. Pumpkin seedlings become more resistant to $P$. capsici as they mature (26), and squash fruit exhibit age-related resistance as they transition from the waxy green to green stage (1). Cucumber roots and foliage are somewhat tolerant to $P$. capsici but fruit are extremely susceptible (21). Fruit may exhibit sunken, discolored lesions, and pathogen signs of white, powdery growth (mycelia and sporangia) while in the field or postharvest. Producers have had entire loads of cucurbit fruit

Corresponding author: M. K. Hausbeck, E-mail: hausbec1@msu.edu

Accepted for publication 20 March 2012.

doi:10.1094/PDIS-09-11-0771-RE

(C) 2012 The American Phytopathological Society rejected due to postharvest rot (21). Disease is favored by warm, wet weather (21), and inocula are disseminated by irrigation water, field runoff, or hard, driving rain $(20,43)$.

Chemical and cultural management of Phytophthora fruit and root rot and foliar blight is challenging. P. capsici overwintering structures (oospores) have been found to survive in the soil and cause subsequent infection for up to 5 years, making rotations to nonsusceptible crops ineffective (21). Resistance to mefenoxam, an oomycete-specific fungicide, is common among isolates in Michigan $(21,25)$, other U.S. states $(8,9,11,28,33,34,43)$, and globally $(35,46)$, where mefenoxam has been greatly utilized. Surface water has been identified as a potential source of $P$. capsici inoculum (15), and asexual propagules (zoospores) may survive in water and remain infectious for up to 5 days at a wide range of temperatures ( 9 to $32^{\circ} \mathrm{C}$ ) (18). Increased plant spacing to decrease the duration of foliar and fruit wetness and canopy humidity, utilization of drip or furrow irrigation from nonsurface water sources, and employment of black plastic mulch to lessen tissue contact with infested soil $(4,15,30,42,43)$ may be practical in some production systems.

Cultivar resistance, in combination with chemical and cultural management practices, may aid in lessening disease occurrence and severity. 'Danmatmaedol,' a Korean pumpkin cultivar, has exhibited increased tolerance to root and crown rot (26). Cucurbita pepo and C. moschata Duchesne accessions were screened, and several plant introduction (PI) lines with reduced crown rot symptoms were observed $(6,32)$. Conversely, fruit screening of a large collection of cucumber germplasm accessions did not identify any resistant genotypes (17). Some studies have indicated that seedling and fruit disease responses of cucurbitaceous and solanaceous crops are dependent upon isolate virulence $(14,22,26,36,40,48)$.

Phytophthora root, crown, and fruit rot is an annual concern for the Michigan cucurbit industry (21). There are no commercial cucurbit cultivars available with significant resistance to $P$. capsici, and land that is not infested with inocula is becoming limited in Michigan (21). Not only is $P$. capsici mefenoxam resistance a significant concern for growers but also use of methyl bromide 
(MeBr), a soil fumigant utilized for reducing disease caused by soilborne pathogens, has been phased out for Michigan growers. They were allowed Critical Use Exemptions from the Environmental Protection Agency (21) to use $\mathrm{MeBr}$ for fresh-market cucurbit and solanaceous crops through 2011; now, $\mathrm{MeBr}$ is no longer an option. Hence, for Michigan growers, knowledge of cucurbit plant and fruit susceptibility to $P$. capsici would help to increase the likelihood of early-season seedling survival and mid-season vigorous crop growth and to decrease the probability of late-season fruit infection.

The objectives of this research included (i) evaluating the susceptibility of cucurbits to root, crown, and fruit rot caused by $P$. capsici; (ii) evaluating the differences in susceptibility of summer and winter squash cultivars to root and crown rot; and (iii) evaluating the virulence of $P$. capsici isolates on cucurbits, to overall advance integrated pest management programs for Michigan growers.

\section{Materials and Methods}

Isolate selection and maintenance. Five $P$. capsici isolates were used as inocula in fruit and seedling experiments (Table 1). Isolates differed in phenotype (mating type = compatibility type $[\mathrm{CT}]$ and sensitivity to mefenoxam [MS]) and host origin (Table 1) and were characterized by $\mathrm{CT}$ and MS as described by Lamour and Hausbeck (25). Isolates SF3, OP97, SP98, and 12889 were collected from commercial fields in Michigan and have been shown to be highly virulent on diverse hosts $(14,17,37,40)$. Agar plugs of isolate cultures were obtained from long-term storage (microcentrifuge tubes containing $1 \mathrm{ml}$ of sterile water and 1 sterile hemp seed at $20^{\circ} \mathrm{C}$ ) and were plated on unclarified V8 juice agar (UCV8; $16 \mathrm{~g}$ of agar, $3 \mathrm{~g}$ of calcium chloride $\left[\mathrm{CaCO}_{3}\right], 160 \mathrm{ml}$ of $\mathrm{V} 8$ juice, and $840 \mathrm{ml}$ of distilled water) amended with $0.50 \mathrm{~g}$ of benomyl, $2 \mathrm{ml}$ of ampicillin, and $2 \mathrm{ml}$ of rifampicin. Mycelia and sporangia agar plugs from 5- to 7-day old cultures were used to inoculate cucumber fruit prior to use in experiments to confirm isolate pathogenicity. Symptomatic tissue was isolated from inoculated cucumber and plated on BARP-amended UCV8 agar (12 g of agar, $0.3 \mathrm{~g}$ of $\mathrm{CaCO}_{3}, 40 \mathrm{ml}$ of $\mathrm{V} 8$ juice, $960 \mathrm{ml}$ of distilled water, $0.50 \mathrm{~g}$ of benomyl, $2 \mathrm{ml}$ of ampicillin, $2 \mathrm{ml}$ of rifampicin, and $0.10 \mathrm{~g}$ of pentachloronitrobenzene). Cultures were observed using a compound microscope at $\times 100$ magnification to confirm $P$. capsici morphological characteristics according to Waterhouse (51), hyphal tipped, and transferred to new UCV8 agar. Cultures were maintained at room temperature $\left(21\right.$ to $\left.23^{\circ} \mathrm{C}\right)$ under continuous fluorescent lighting and were transferred every 5 to 7 days to new UCV8 agar.

Fruit experiment. Screening of summer squash and cucumber fruit, including straightneck squash (C. pepo), zucchini (C. pepo), pickling cucumber, and slicing cucumber, for susceptibility to $P$. capsici was conducted in July 2009 in the laboratory of M. K. Hausbeck at Michigan State University (MSU; Table 2). Screening of winter squash fruit, including acorn squash (C. pepo), butternut squash (C. moschata), spaghetti squash (C. pepo), and pumpkin, for susceptibility to $P$. capsici was conducted in September 2009 in a greenhouse at the MSU Plant Science Research Greenhouses in East Lansing, MI (Table 2). The experimental design was a split plot arrangement and the experiment was repeated three times.

Table 1. Compatibility type, sensitivity to mefenoxam, and host origin of Phytophthora capsici isolates used in fruit and seedling experiments

\begin{tabular}{lccl}
\hline Isolate $^{\mathbf{x}}$ & CT $^{\mathbf{y}}$ & Sensitivity $^{\mathbf{z}}$ & \multicolumn{1}{c}{ Host origin } \\
\hline SF3 & A1 & IS & Pickling cucumber (Cucumis sativus) \\
OP97 & A1 & S & Pickling cucumber (C. sativus) \\
SP98 & A2 & S & Pumpkin (Cucurbita pepo) \\
12889 & A1 & I & Pepper (Capsicum annuum) \\
13351 & A1 & S & Eggplant (Solanum melongena) \\
\hline
\end{tabular}

${ }^{\mathrm{x}}$ Isolate designation refers to the notation given by the laboratory of M. K. Hausbeck at Michigan State University.

${ }^{\text {y }} \mathrm{CT}=$ compatibility type, mating type.

${ }^{\mathrm{z}}$ Mefenoxam sensitivity. IS = intermediately sensitive, $\mathrm{S}=$ sensitive, and I = insensitive to mefenoxam.
Fruit type was considered the whole-plot factor and pathogen isolate was considered the subplot factor. One fruit was an experimental unit, and each fruit type was replicated eight times for each isolate and the control. Fruit were obtained from plants grown in commercial fields or MSU research farms with no history of Phytophthora rot occurrence, were hand-harvested at maturity, and were of a commercially marketable and similar size (Table 2).

In the field, slicing cucumber and squash plants were treated with fungicides that do not significantly impact $P$. capsici, including chlorothalonil (Bravo Weather Stik; Syngenta Crop Protection, Inc., Greensboro, NC) at 1.75 liters a.i./ha, thiophanate-methyl (Topsin 4.5FL; Cerexagri Inc., King of Prussia, PA) at 0.59 liter a.i./ha, and copper hydroxide (Kocide 2000; DuPont Crop Production, Wilmington, DE [winter squash only]) at 0.11 a.i./ha at 10day intervals; pickling cucumber and pumpkin plants were treated with chlorothalonil (Bravo Weather Stik) at 2.33 liters a.i./ha, alternated with pyraclostrobin (Cabrio; BASF Ag Products, Research Triangle Park, NC) at 1.29 liters a.i./ha at 7-day intervals for control of powdery and downy mildews. Pumpkin plants were treated with imidacloprid (Admire Pro; Bayer CropScience, Research Triangle Park, NC) at 0.73 liter a.i./ha at transplanting and esfenvalerate (Asana XL; DuPont Crop Protection) at 0.70 liter a.i./ha at flowering for control of cucumber beetles. Plants were irrigated and fertilized according to standard management practices.

Fruit were inoculated according to the method described by Gevens et al. (17). Fruit were surface disinfested in a $20 \%$ bleach $(1.23 \%$ sodium hypochlorite $[\mathrm{NaClO}])$ solution for $5 \mathrm{~min}$ and rinsed with distilled water prior to inoculation. Fruit were allowed to air dry and then placed into clear incubation chambers ( 23 by 10 by $32 \mathrm{~cm}$; Potomac Display, Hampstead, MD) disinfested with $70 \%$ ethanol (EtOH). Moist paper towels were placed in chambers to maintain high relative humidity. One 5 -mm-diameter plug of UCV8 agar with actively growing mycelia and sporangia from the edge of a 5- to 7-day-old culture was used to inoculate unwounded fruit. Control fruit were inoculated with uncolonized agar. Plugs were placed on each fruit near the blossom end. Each plug was covered with a sterile cap removed from a $1.7-\mathrm{ml}$ microcentrifuge tube to prevent desiccation. Caps were affixed to the fruit surface with petroleum jelly. Chambers were placed side by side on a laboratory bench under continuous fluorescent lighting at room temperature (Fig. 1A). A Watchdog data logger (450 series; Spectrum Technologies, Inc., East Plainfield, IL) was placed in one chamber to monitor temperature and relative humidity. Temperature and relative humidity were recorded every $30 \mathrm{~min}$, and recordings were used to calculate mean air temperature and relative humidity. Mean air temperature and relative humidity were $21.9^{\circ} \mathrm{C}\left( \pm 2.9^{\circ} \mathrm{C}\right)$ and $96.1 \%( \pm 3.8 \%)$, respectively.

Winter squash fruit were inoculated as described above, with the exception that fruit were wounded to a depth of 3 to $5 \mathrm{~mm}$ with a sterile probe before inoculation and caps were affixed to the fruit

Table 2. Cucurbit fruit evaluated for susceptibility to fruit rot caused by Phytophthora capsici

\begin{tabular}{llc}
\hline Crop species & \multicolumn{1}{c}{ Cultivar } & $\begin{array}{c}\text { Mean fruit } \\
\text { diameter }(\mathbf{c m})\end{array}$ \\
\hline $\begin{array}{l}\text { Cucumis sativus } \\
\text { Pickling cucumber }\end{array}$ & Vlaspik $^{\mathrm{y}}$ & $2.7-3.0$ \\
$\begin{array}{l}\text { Slicing cucumber } \\
\text { Cucurbita moschata }\end{array}$ & Cobra $^{\mathrm{y}}$ & $4.0-5.0$ \\
Butternut squash & Butternut Supreme $^{\mathrm{z}}$ & $10.5-12.0$ \\
C. pepo & & \\
Acorn squash & Table Ace $^{\mathrm{z}}$ & $11.0-12.0$ \\
Pumpkin & Sorcerer $^{\mathrm{z}}$ & $23.0-26.5$ \\
Spaghetti squash & Vegetable $^{\mathrm{z}}$ & $11.0-14.0$ \\
Straightneck squash & Cougar $^{\mathrm{y}}$ & $4.0-4.5$ \\
& Fortune $^{\mathrm{y}}$ & $4.0-4.5$ \\
Zucchini & Reward $^{\mathrm{y}}$ & $4.0-4.5$ \\
& Spineless Beauty $^{\mathrm{y}}$ & $4.0-4.5$ \\
\hline
\end{tabular}

${ }^{\mathrm{y}}$ Fruit evaluated in the laboratory.

${ }^{\mathrm{z}}$ Fruit evaluated in the greenhouse. 
surface with clear tape. Attaching the cap to the surface by petroleum jelly was not successful in preventing moisture loss from the $P$. capsici plug in the greenhouse (tested prior to fruit experiments; data not shown). Inoculated fruit were placed into individual clear, plastic bags on disinfested greenhouse benches (Fig. 1B). Bags contained moist paper towels to maintain high relative humidity and were held closed with a rubber band. Natural light was supplemented with high-intensity discharge lamps from sunset to sunrise. Temperature and relative humidity in one bag were recorded hourly using a Watchdog data logger, and recordings were used to calculate mean air temperature and relative humidity. Mean air temperature and relative humidity were $22.1{ }^{\circ} \mathrm{C}\left( \pm 2.7^{\circ} \mathrm{C}\right)$ and $94.7 \%( \pm 4.2 \%)$, respectively.

Disease was evaluated 3 and 5 days post inoculation (dpi) for summer squash and cucumber, and 3, 6, and 8 dpi for winter squash. Lesion and pathogen growth diameters were measured perpendicularly (Fig. 1C). Pathogen growth density was assessed on a 0 -to- 3 scale, where $0=$ no growth, $1=$ visible but minimal growth, 2 = moderate growth, and $3=$ dense growth. Upon experiment completion, four pieces of tissue were excised from the margin of symptomatic lesions from $50 \%$ of randomly selected fruit inoculated with each $P$. capsici isolate. Asymptomatic control fruit were also sampled. Tissues were plated onto BARP-amended UCV8 agar. Cultures were observed 3 days after plating using a compound microscope at $\times 100$ magnification and confirmed as $P$. capsici based on morphological characteristics according to Waterhouse (51). Isolates were characterized by CT and MS as previously described (25). Phenotype of the recovered isolates was compared with the original inoculum.

Statistical analyses. Mean diameter was calculated for lesion and pathogen growth by averaging two perpendicular diameter measurements for the two response variables. Mean lesion and pathogen growth diameters were analyzed by analysis of variance
(ANOVA) using the PROC MIXED procedure of SAS (version 9.2; SAS Institute Inc., Cary, NC). If variances were heterogeneous for fruit type or pathogen isolate, the GROUP option of the REPEATED statement (with the lowest AIC value) was used with degrees of freedom according to Kenward-Roger. If ANOVA was significant for main effects or interaction terms, treatment means were compared using Fisher's protected least significant difference (LSD) test at $P=0.05$. Interactions were examined by slicing. Pathogen growth density was analyzed by proportional odds (or partial proportional odds if the $\chi^{2}$ score test for proportional odds assumption was not valid for the model) using the PROC LOGISTIC procedure of SAS version 9.2 (or the PROC GENMOD procedure of SAS version 9.2 if the partial proportional odds model was applied). The proportional odds model is a logistic regression analysis procedure appropriate for ordinal response data (29). Fruit of the same type (summer squash [straightneck squash and zucchini], cucumber [pickling and slicing cucumber], and winter squash [acorn squash, butternut squash, pumpkin, and spaghetti squash]) were grouped together for analyses. Disease was not observed on nor was $P$. capsici recovered from control fruit, which were removed from all data sets prior to analyses.

Seedling experiments. In experiment 1 , acorn squash, pumpkin, semi-crookneck squash (C. pepo), and zucchini were grown to evaluate seedling susceptibility among crops (Table 3 ). In experiment 2, two cultivars each of butternut squash, straightneck squash, and zucchini were grown to evaluate seedling susceptibility between cultivars of the same crop (Table 3). 'Butterbush' butternut squash was included as a highly susceptible cultivar (31). Experiments were conducted in August 2009 (experiment 1) and December 2009 (experiment 2) at the MSU Plant Science Research Greenhouses. The experimental design for both experiments was a split-plot arrangement of a randomized complete block design Pathogen isolate was considered the whole-plot factor and crop

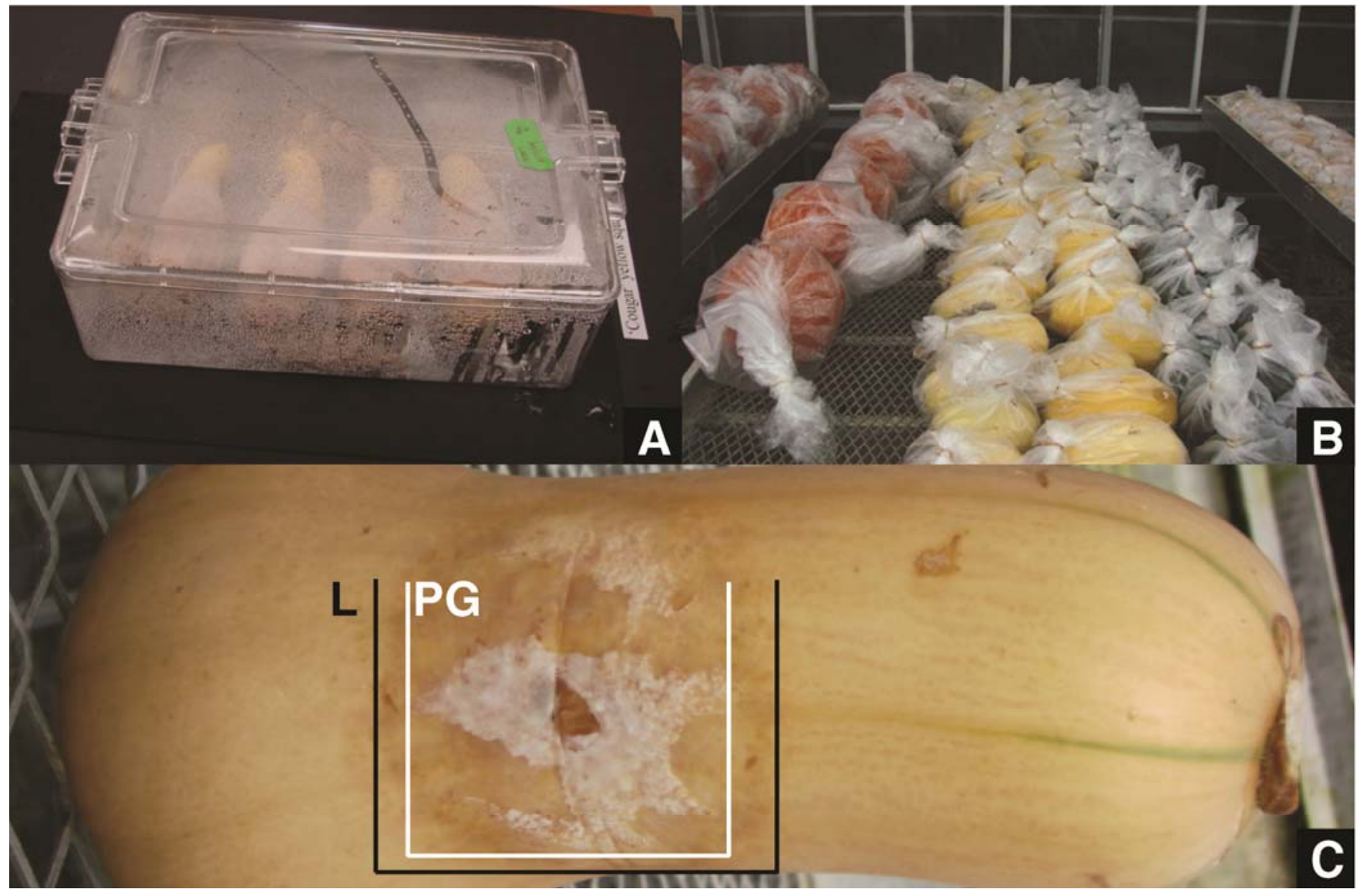

Fig. 1. Cucurbit fruit inoculation techniques used to evaluate susceptibility to fruit rot following inoculation with Phytophthora capsici. A, Fruit incubating in a clear chamber in the laboratory at high humidity. B, Large fruit in individual clear bags to maintain humidity in the greenhouse. C, Butternut squash fruit 6 days post inoculation. Note lesion (L) and pathogen growth (PG) diameter. 
type was considered the subplot factor. Both experiments were conducted three times. Seedlings were replicated eight times for each isolate and the control.

In experiment 1 (run 1), seed were directly sown into square 1.5liter pots in the greenhouse using soilless potting media (Baccto Professional Planting Mix; Michigan Peat Company, Houston). In experiments 1 (runs 2 and 3) and 2, seed were sown in 128-cell plug trays filled with potting media, and seedling replicates were transplanted into individual 1.5-liter pots 7 days prior to inoculation. Seedlings were grown under a 14-h photoperiod in the greenhouse. Seedlings were watered as necessary and fertilized three times weekly with Peter's 20-20-20 soluble liquid fertilizer (The
Scott's Company, Marysville, OH) at $200 \mathrm{ppm}$ and were acid treated once weekly with $10 \%$ phosphoric acid to allow for an appropriate potting soil $\mathrm{pH}$ conducive for plant growth. Air temperature and relative humidity were monitored using a Watchdog data logger every $30 \mathrm{~min}$, and recordings were used to calculate mean air temperature and relative humidity. Mean air temperature and relative humidity for experiment 1 were $23.1^{\circ} \mathrm{C}\left( \pm 6.8^{\circ} \mathrm{C}\right)$ and $40.3 \%( \pm 34.5 \%)$, respectively; mean air temperature and relative humidity for experiment 2 were $22.5^{\circ} \mathrm{C}\left( \pm 7.3^{\circ} \mathrm{C}\right)$ and $21.1 \%$ $( \pm 2.2 \%)$, respectively.

Seedlings were inoculated at the two- to three-true-leaf stage $(26,32)$ with infested millet seed prepared according to the meth-

Table 3. Cucurbit seedlings evaluated in greenhouse experiments for susceptibility to root and crown rot caused by Phytophthora capsici

\begin{tabular}{lll}
\hline Crop species & Cultivar & Seed source \\
\hline $\begin{array}{l}\text { Cucurbita moschata } \\
\text { Butternut squash }\end{array}$ & $\begin{array}{l}\text { Butterbush }^{\mathrm{y}} \\
\text { Waltham }^{\mathrm{y}}\end{array}$ & Burpee Seeds, PA \\
$\begin{array}{l}\text { Cucurbita pepo } \\
\text { Acorn squash }\end{array}$ & Table Ace & \\
Pumpkin & Trojan $^{\mathrm{z}}$ & Seedway, LLC, MA \\
Semi-crookneck squash & Gold Star $^{\mathrm{z}}$ & Seedway, LLC, MA \\
Straightneck squash & Cougary $^{\mathrm{y}}$ & Rogers Brand Vegetable Seed, ID \\
& Lioness $^{\mathrm{y}}$ & Harris Moran Seed Co., CA \\
Zucchini & Leopardy, $^{\mathrm{y}, \mathrm{z}}$ & Harris Moran Seed Co., CA \\
& Zucchini Elite & Harris Seeds, NY \\
\hline
\end{tabular}

${ }^{\mathrm{y}}$ Seedlings evaluated in experiment 2 .

${ }^{\mathrm{z}}$ Seedlings evaluated in experiment 1.

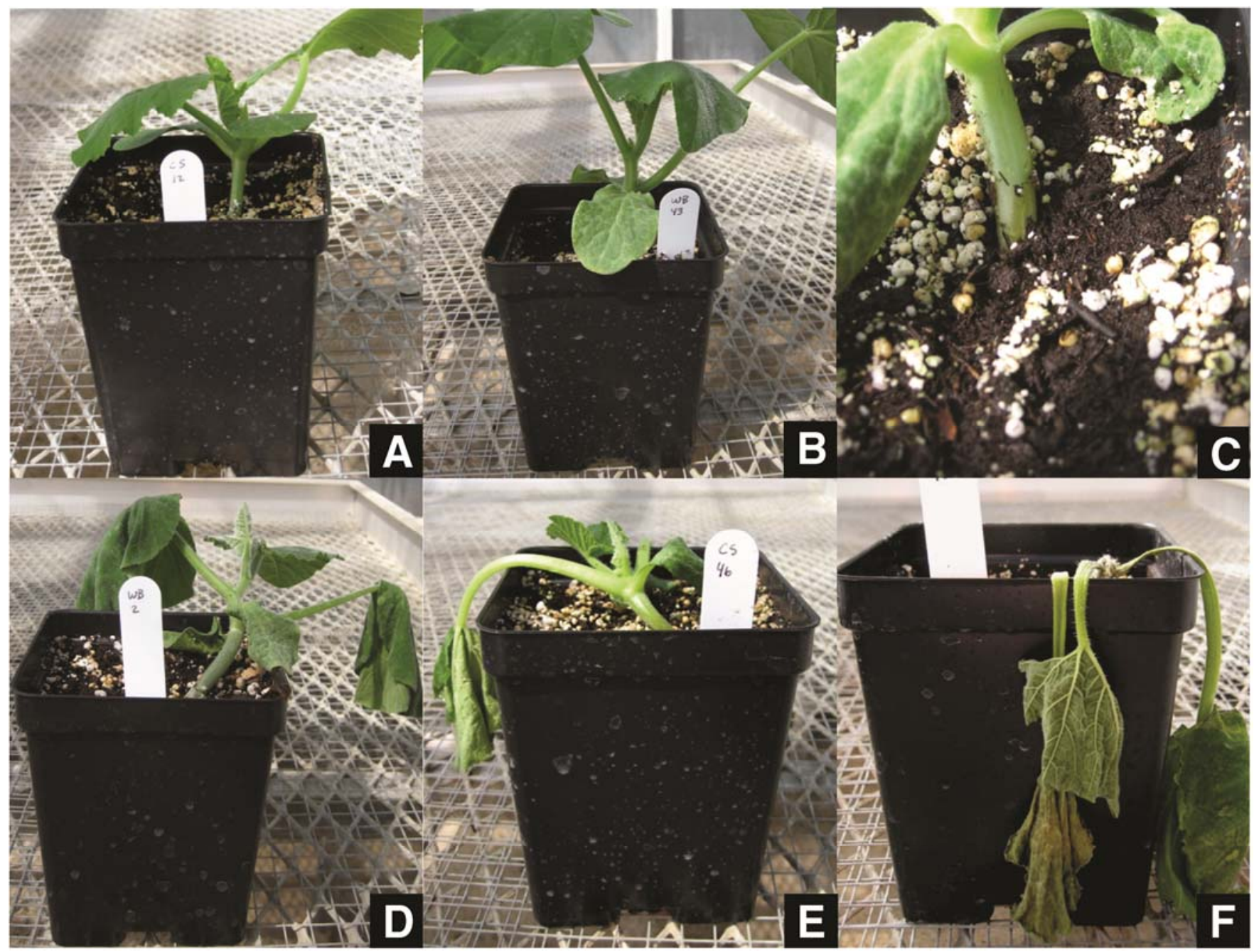

Fig. 2. Disease severity rating scale used to evaluate seedling susceptibility to root and crown rot caused by Phytophthora capsici, where $\mathbf{A}, 0=$ no visible symptoms; $\mathbf{B}, 1=$ leaves slightly wilted; $\mathbf{C}, 2=$ foliar wilting with crown lesion present at soil line; $\mathbf{D}, 3=$ plant partially collapsed; $\mathbf{E}, 4=$ plant completely collapsed; and $\mathbf{F}, 5=$ death. 
ods of Quesada-Ocampo et al. (37). Approximately $1 \mathrm{~g}$ of infested millet seed was added to the top of potting media around seedling stems. Sterile millet seed were used to inoculate control plants. Seedlings were watered after inoculation to prevent immediate inoculum desiccation and to evenly distribute seed on the potting media surface. Seedlings inoculated with different isolates were spaced $0.3 \mathrm{~m}$ apart.

Seedlings were inspected for aboveground symptoms. Disease severity was evaluated at 2-day intervals from 0 to 14 dpi on a rating scale adapted from Padley et al. (32), where $0=$ no visible symptoms, $1=$ leaves slightly wilted, $2=$ foliar wilting with crown lesion present at soil line, 3 = plant partially collapsed, $4=$ plant completely collapsed, and $5=$ death (Fig. 2). Upon experiment completion, randomly selected controls and seedlings (approximately $12.5 \%$ of each treatment) inoculated with each $P$. capsici isolate were gently rinsed with water to remove excess potting media. Foliage and roots were removed and crowns were surface disinfested with $70 \% \mathrm{EtOH}$ for $1 \mathrm{~min}$ and air dried. Four sections of tissue were aseptically excised from the crown and plated on BARP-amended UCV8 agar. Cultures were observed 3 days after plating using a compound microscope at $\times 100 \mathrm{mag}$ nification and confirmed as $P$. capsici based on morphological characteristics according to Waterhouse (51). Isolates were characterized by CT and MS as previously described (25). Phenotype of the recovered isolates was compared with the original inoculum.

Statistical analyses. The area under the disease progress curve (AUDPC) was calculated from disease severity ratings according to the formula of Shaner and Finney (45). AUDPC values and symptom appearance dpi data were analyzed by ANOVA using the PROC MIXED procedure of SAS version 9.2. Symptom appearance dpi were subjected to the PROC NLIN procedure prior to using PROC MIXED to satisfy normality assumptions. If variances were heterogeneous for crop type or pathogen isolate, the GROUP option of the REPEATED statement (with the lowest AIC value) was used with degrees of freedom according to KenwardRoger. If ANOVA was significant for main effects or interaction terms, treatment means were compared using Fisher's protected LSD test at $P=0.05$. Interactions were examined by slicing. Disease was not observed on nor was $P$. capsici recovered from control seedlings in experiments 1 and 2, which were removed from the data sets prior to analyses.

\section{Results}

Fruit experiment. All five $P$. capsici isolates incited disease, and tissue isolations confirmed recovered isolates to have the same phenotype as the original inoculum (data not shown). Control fruit did not exhibit disease symptoms, nor was $P$. capsici recovered from isolations from these fruit.

Water-soaked lesions and pathogen growth were visible on summer squash 3 dpi and were markedly increased 5 dpi. Within summer squash, lesion (5 dpi) and pathogen growth diameter (3 and 5 dpi) varied by fruit type (Table 4$)$. Straightneck squash had larger lesions $(8.0 \mathrm{~cm})$ compared with zucchini $(6.1 \mathrm{~cm}) 5$ dpi (Fig. $3 \mathrm{~A})$ and more pathogen growth at $3 \mathrm{dpi}(1.4 \mathrm{~cm})$ and $5 \mathrm{dpi}(7.4 \mathrm{~cm})$ compared with zucchini $(3 \mathrm{dpi}=0.7 \mathrm{~cm}$ and $5 \mathrm{dpi}=5.1 \mathrm{~cm}$; Fig. 3A). Likewise, pathogen growth density 3 and 5 dpi was dependent on fruit type. Straightneck squash had higher odds 3 dpi (odds = 3.6) and 5 dpi (odds $=2.5$ ) of having more dense pathogen growth compared with zucchini (data not shown).

Lesion and pathogen growth diameter in summer squash also varied by pathogen isolate 3 and 5 dpi (Table 4). Isolate SF3 caused smaller lesions compared with other isolates (Figs. 4A and 5A). At 5 dpi, isolates 12889 and 13351 caused larger lesions (8.5 and $8.4 \mathrm{~cm}$, respectively) compared with other isolates (Fig. 5A). At $3 \mathrm{dpi}, \mathrm{SF} 3$ had no pathogen growth $(0.0 \mathrm{~cm})$ and had reduced growth $(2.2 \mathrm{~cm})$ compared with other isolates 5 dpi (Figs. 4A and $5 \mathrm{~A})$. At $5 \mathrm{dpi}$, isolates 12889 and 13351 had more pathogen growth (7.7 and $7.9 \mathrm{~cm}$, respectively) compared with other isolates (Fig. $5 \mathrm{~A})$. After isolate SF3 was removed from the 3 dpi data set, pathogen growth density did not vary $(P=0.5335)$. At 5 dpi, isolates OP97, SP98, 12889, and 13351 had similar odds of being the same density on both fruit types, whereas isolate SF3 was more likely (odds $=12.1, P<0.0001$ ) to growing denser on straightneck squash compared with zucchini (data not shown).

Disease was observed on cucumber $3 \mathrm{dpi}$. The magnitude of the effect of fruit type for lesion diameter 3 dpi was dependent upon pathogen isolate. Due to the significant interaction (Table 4), pathogen isolates were analyzed separately. For each isolate, lesion diameter varied within fruit type. Isolate SF3 caused smaller lesions (pickling cucumber $=1.4 \mathrm{~cm}$ and slicing cucumber $=0.4 \mathrm{~cm}$ ) on both fruit types compared with other isolates (Fig. 6). Isolate SP98 caused larger lesions $(3.2 \mathrm{~cm})$ on slicing cucumber compared with isolates OP97 and SF3 (Fig. 6). Lesions on slicing cucumber were larger than those on pickling cucumber, with the exception of those caused by isolate SF3 (Fig. 6).

Within cucumber, lesion (5 dpi) and pathogen growth diameter (3 dpi) varied by fruit type (Table 4$)$. Slicing cucumber had larger lesions and more pathogen growth $(7.3$ and $0.5 \mathrm{~cm}$, respectively) compared with pickling cucumber $(6.3$ and $0.05 \mathrm{~cm}$, respectively) (Fig. 3B). Pathogen growth density was dependent on fruit type 3 dpi $(P=0.0002)$; slicing cucumber had higher odds (odds $=7.3)$ of having any pathogen growth compared with pickling cucumber (data not shown).

Table 4. Probability values of the main effects and interaction effect obtained in the fruit rot susceptibility experiment 3 and 5 days post inoculation (dpi) for summer squash and cucumber and 6 and 8 dpi for winter squash

\begin{tabular}{|c|c|c|c|c|c|c|c|c|}
\hline \multirow[b]{3}{*}{ Effect } & \multicolumn{8}{|c|}{$P$ value $^{w}$} \\
\hline & \multicolumn{4}{|c|}{ Lesion diameter } & \multicolumn{4}{|c|}{ Pathogen growth diameter } \\
\hline & 3 dpi & 5 dpi & 6 dpi & 8 dpi & 3 dpi & $5 \mathrm{dpi}$ & 6 dpi & 8 dpi \\
\hline \multicolumn{9}{|l|}{ Summer squash ${ }^{\mathrm{x}}$} \\
\hline Fruit type & $0.0524 \mathrm{~ns}$ & $<0.0001 *$ & $\ldots$ & $\ldots$ & $0.0372 *$ & $<0.0001^{*}$ & $\ldots$ & $\ldots$ \\
\hline Isolate & $0.0253^{*}$ & $<0.0001^{*}$ & $\ldots$ & $\ldots$ & $0.0273 *$ & $<0.0001 *$ & $\ldots$ & $\ldots$ \\
\hline Type $\times$ isolate & $0.8762 \mathrm{~ns}$ & $0.9294 \mathrm{~ns}$ & $\ldots$ & $\ldots$ & $0.6742 \mathrm{~ns}$ & $0.9529 \mathrm{~ns}$ & $\ldots$ & $\ldots$ \\
\hline \multicolumn{9}{|l|}{ Cucumber $^{\mathrm{y}}$} \\
\hline Fruit type & $0.0002 *$ & $<0.0001^{*}$ & $\ldots$ & $\ldots$ & $0.0235^{*}$ & $0.0484 \mathrm{~ns}$ & $\ldots$ & $\ldots$ \\
\hline Isolate & $<0.0001^{*}$ & $<0.0001 *$ & $\ldots$ & $\ldots$ & $0.2400 \mathrm{~ns}$ & $<0.0001$ & $\ldots$ & $\ldots$ \\
\hline Type $\times$ isolate & $<0.0001^{*}$ & $0.5056 \mathrm{~ns}$ & $\ldots$ & $\ldots$ & $0.2728 \mathrm{~ns}$ & $0.7539 \mathrm{~ns}$ & $\ldots$ & $\ldots$ \\
\hline \multicolumn{9}{|l|}{ Winter squash ${ }^{\mathrm{z}}$} \\
\hline Fruit type & $\ldots$ & $\ldots$ & $0.0009^{*}$ & $0.0002 *$ & $\ldots$ & $\ldots$ & $0.0007^{*}$ & $<0.0001^{*}$ \\
\hline Isolate & $\ldots$ & $\ldots$ & $<0.0001 *$ & $<0.0001 *$ & $\ldots$ & $\ldots$ & $<0.0001^{*}$ & $<0.0001^{*}$ \\
\hline Type $\times$ isolate & $\ldots$ & $\ldots$ & $0.7647 \mathrm{~ns}$ & $0.7535 \mathrm{~ns}$ & $\ldots$ & $\ldots$ & $0.6257 \mathrm{~ns}$ & $0.4796 \mathrm{~ns}$ \\
\hline
\end{tabular}

${ }^{\text {w}}$ Fisher's protected least significant difference $(P=0.05)$, ns $=$ not significant and $*=$ significant.

${ }^{x}$ Straightneck squash and zucchini.

y Pickling and slicing cucumber.

z Acorn, butternut, and spaghetti squash and pumpkin. 
Lesion and pathogen growth diameter on cucumber varied by pathogen isolate 5 dpi (Table 4). On fruit, isolate SF3 caused smaller lesions $(4.6 \mathrm{~cm})$ and had reduced pathogen growth (1.9 $\mathrm{cm}$ ) compared with other isolates (Figs. 4B and 5B). Pathogen growth density 3 dpi was dependent on pathogen isolate $(P=$ 0.0002); isolate SP98 had higher odds of having any growth on fruit compared with isolates SF3 (odds $=16.2$ ), OP97 (odds $=7.5$ ), 12889 (odds $=10.4)$, and 13351 (odds = 3.2) $($ data not shown $)$. At 5 dpi, isolates SF3, OP97, SP98, and 12889 had similar odds of producing the same density on both fruit types, whereas isolate 13351 had higher odds (odds $=16.7, P=0.0108$ ) of being more dense on slicing cucumber compared with pickling cucumber (data not shown).

Disease was infrequently observed on winter squash 3 dpi (data not shown); however, lesions and pathogen growth were observed on all fruit types 6 dpi. Lesion and pathogen growth diameter varied by fruit type 6 and 8 dpi (Table 4). Butternut squash had larger lesions compared with pumpkin and spaghetti squash 6 dpi $(5.3$ $\mathrm{cm})$ and $8 \mathrm{dpi}(9.3 \mathrm{~cm})$ (Fig. 3C). Acorn and butternut squash and pumpkin had similar pathogen growth diameters, greater than spaghetti squash 6 dpi $(1.2 \mathrm{~cm}$; Fig. 3C). At $8 \mathrm{dpi}$, pumpkin and spaghetti squash had reduced pathogen growth diameters compared with acorn and butternut squash (Fig. 3C). Pathogen growth density was dependent on fruit type 6 and 8 dpi $(P<0.0001)$. At 6 dpi, acorn squash had similar odds of having any pathogen growth compared with butternut squash (odds $=1.2$ ) and higher odds than pumpkin and spaghetti squash (odds $=3.1$ and 7.4, respectively) (data not shown). Acorn squash had higher odds of having a rating of no or minimal pathogen growth density compared with butternut squash (odds $=1.4$ ), lower odds than pumpkin (odds $=0.7$ ), and higher odds than spaghetti squash (odds =1.9) (data not shown). Acorn squash had similar odds of having a rating of moderate to dense pathogen growth density compared with butternut and spaghetti squash (odds $=1.1$ and 1.2, respectively) and lower odds than pumpkin (odds $=0.2)$ (data not shown). At 8 dpi, acorn squash had higher odds of having any pathogen growth compared with all other fruit, specifically butternut squash (odds $=1.4$ ), pumpkin (odds $=5.4)$, and spaghetti squash (odds = 6.8) $($ data not shown). Acorn squash had lower odds of having a rating of no or minimal pathogen growth density compared with butternut squash (odds $=0.5)$, similar odds to pumpkin (odds $=1.1$ ), and higher odds than spaghetti squash (odds $=2.9$ ) (data not shown). Acorn squash had lower odds of having a rating of moderate to dense pathogen growth compared with butternut squash and pumpkin (odds $=0.6$ and 0.1 , respectively) and similar odds to spaghetti squash (odds $=1.1)$ (data not shown).

Lesion and pathogen diameter on winter squash varied by pathogen isolate 6 and 8 dpi (Table 4). Isolate 13351 caused larger lesions $(5.6 \mathrm{~cm}) 6 \mathrm{dpi}$ and had greater pathogen growth $(3.9 \mathrm{~cm})$ compared with isolates SF3, OP97, and 12889 (Fig. 5C). At 8 dpi, isolate 13351 caused larger lesions $(10.2 \mathrm{~cm})$ with more pathogen growth $(8.3 \mathrm{~cm})$ compared with other isolates (Figs. $4 \mathrm{C}$ and $5 \mathrm{C}$ ). Isolate SF3 caused smaller lesions 6 and 8 dpi $(1.8$ and $3.4 \mathrm{~cm}$, respectively) with reduced pathogen growth $(0.6$ and $1.6 \mathrm{~cm}$, respectively) (Figs. 4C and 5C). Pathogen growth density 6 and 8 dpi was dependent upon pathogen isolate $(P<0.0001)$. Isolate 13351 had higher odds of being more dense on fruit compared with other isolates $6 \mathrm{dpi}$; specifically, isolates SF3 (odds $=11.3$ ), OP97 $($ odds $=1.4)$, SP98 (odds $=1.4)$, and 12889 (odds = 2.5) $($ data $n o t$ shown). Likewise, $8 \mathrm{dpi}$, isolate 13351 was likely to have denser growth on fruit compared with other isolates; specifically, isolates SF3 $($ odds $=8.5)$, OP97 $($ odds $=1.8)$, SP98 $($ odds $=1.8)$, and 12889 (odds $=2.4)$ (data not shown).

Seedling experiments. All isolates incited disease on squash seedlings, and tissue isolations confirmed recovered isolates to have the same phenotype as the original inoculum (data not shown). Control seedlings did not exhibit disease symptoms, nor was $P$. capsici recovered from tissue isolations from these seedlings.

The magnitude of the effect of crop type for symptom appearance was dependent upon pathogen isolate in experiment 1 . Due to the significant interaction $(P=0.0169)$, pathogen isolates were analyzed separately. Symptom appearance varied within crop type for each isolate, except for isolate SF3. Semi-crookneck squash inoculated with isolates OP97, SP98, 12889, and 13351 exhibited
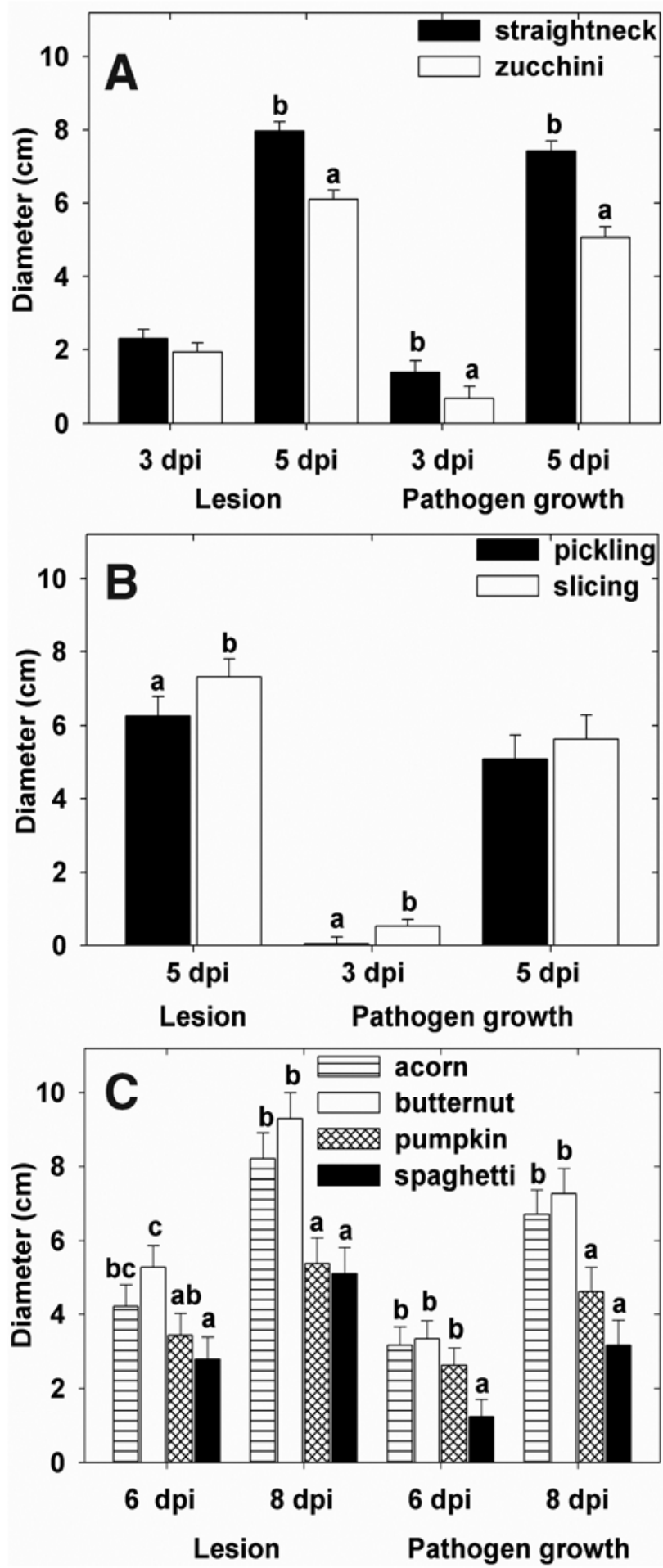

Fig. 3. Lesion and pathogen growth diameters observed on $\mathbf{A}$, summer squash (straightneck squash and zucchini); B, cucumber (pickling and slicing cucumber); and $\mathbf{C}$, winter squash (acorn squash, butternut squash, pumpkin, and spaghetti squash) fruit following inoculation with five Phytophthora capsici isolates. Disease was evaluated 3 and 5 days post inoculation (dpi) in fruit experiment for summer squash and cucumber and 6 and 8 dpi for winter squash. Bars with a letter in common are not significantly different for each response variable within each dpi (Fisher's protected least significant difference, $P=0.05$ ). Bars represent + standard error. Disease was not observed on nor was $P$. capsici was recovered from control fruit, which were not included in data analyses. 
disease first, on average, approximately 8 dpi (7.7, 7.8, 8.0, and 8.1 dpi, respectively; Fig. 7). Pumpkin inoculated with isolate 13351 developed symptoms between 8 and 9 dpi ( $8.5 \mathrm{dpi})$, earlier than acorn squash and zucchini (Fig. 7). Acorn squash inoculated with isolates OP97, SP98, and 12889 showed disease later than other crops inoculated with these isolates $(11.4,10.7$, and $11.1 \mathrm{dpi}$, respectively). There were no differences regarding symptom onset of isolate SF3 with any cucurbit (Fig. 7).

Variation in AUDPC values was significant by crop type $(P<$ $0.0001)$ and pathogen isolate $(P=0.0003)$. Semi-crookneck squash had the highest AUDPC value (AUDPC $=29$ ), larger than acorn squash, pumpkin, and zucchini (AUDPC $=15,18$, and 15, respectively) (Table 5). Cucurbits inoculated with isolate SF3 had the lowest AUDPC value (AUDPC $=8$ ) and those inoculated with isolates OP97, SP98, 12889, and 13351 had similar AUDPC values (Table 5).

In experiment 2 , symptom appearance varied by crop type $(P=$ 0.0117). 'Cougar' and 'Lioness' straightneck squash and 'Waltham' butternut squash developed symptoms between 9 and 11 dpi (9.6, 9.7, and 10.5 dpi, respectively), before both cultivars of zucchini ('Leopard' = 11.2 and 'Zucchini Elite' = 11.0) and Butterbush butternut squash $(11.1 \mathrm{dpi})$. There was no significant difference between cultivars of the same crop regarding disease onset (data not shown).

The magnitude of the effect of crop type for AUDPC values was dependent upon pathogen isolate in experiment 2. Due to the significant interaction $(P<0.0001)$, pathogen isolates were analyzed separately. Symptom appearance varied within crop type for each isolate, except for isolate SF3. The highest AUDPC value attained was for Cougar straightneck squash inoculated with isolate SP98 (AUDPC = 30; Table 6), which was similar to isolates 12889 and 13351 paired with Cougar. The AUDPC values of Lioness straightneck squash inoculated with any isolate were not different from the AUDPC values of Cougar straightneck squash (Table 6). However, the AUDPC value of Waltham butternut squash inoculated with isolate 13351 (AUDPC $=11$ ) was lower than Butterbush butternut squash (AUDPC $=20$ ). Likewise, the AUDPC value of Zucchini Elite zucchini inoculated with isolate 13351 (AUDPC = 15) was lower than Leopard zucchini (AUDPC = 20). AUDPC values of butternut squash and zucchini cultivars inoculated with isolates SF3, OP97, SP98, and 12889 did not significantly differ from each other (Table 6).

\section{Discussion}

The results of this study indicate that the susceptibility of cucurbits within crop types to $P$. capsici varies. Susceptibility differ- ences were confirmed by differences in lesion and pathogen growth size and pathogen density observed on fruit and differences in symptom appearance and AUDPC values of seedlings.

Similar to what Ando et al. (1) noted, summer squash fruit, including straightneck squash and zucchini, were very susceptible to P. capsici. However, their study did not indicate significant differences in susceptibility between any of the fruit tested (evaluated as the stage of disease progression on fruit surfaces following inoculation). Lesions and pathogen growth were observed on both straightneck squash and zucchini fruit in this study 3 dpi. However, by measuring lesion and pathogen growth size, significant differences in fruit susceptibility were observed $5 \mathrm{dpi}$, with straightneck squash exhibiting greater susceptibility. Grouping similar crop types (summer squash, cucumber, and winter squash) together for analyses lessened the variability among fruit. In this study, slicing cucumber fruit were more susceptible than pickling cucumber, with greater disease (larger lesions) observed at $5 \mathrm{dpi}$.

The inoculation technique developed by Gevens et al. (17), replicated by Ando et al. (1), and modified for use in this study for winter squash was effective in evaluating fruit susceptibility to Phytophthora rot. Also similar to what Ando et al. (1) observed, winter squash fruit exhibited symptoms later than summer squash and cucumber in this study. Acorn and butternut squash were the most susceptible of the winter squash fruit tested, having larger lesions and more pathogen growth compared with pumpkin and spaghetti squash, although the latter were highly susceptible in this experiment.

Differences in virulence were observed among $P$. capsici isolates in the fruit experiment. Isolates 12889 and 13351 were the most virulent on summer squash, and isolate 13351, followed by SP98, were the most virulent on winter squash. Isolates OP97, SP98, 12889, and 13351 were similar in virulence on cucumber fruit Isolate SF3 was significantly less virulent on all fruit. However, isolate SF3 (from pickling cucumber) caused larger lesions on pickling cucumber compared with slicing cucumber 3 dpi. There was no significant difference in lesion size between cucumber fruit inoculated with isolate SF3 5 dpi.

The virulence of $P$. capsici isolates tested differed on seedlings in our experiments. Overall, symptoms on semi-crookneck squash and pumpkin were observed first with isolate 13351, followed by isolates OP97, SP98, and 12889. The AUDPC values of semicrookneck squash and all seedlings inoculated with isolate 13351 were higher than for other cucurbits and isolates, respectively. In experiment 2 , there were no differences observed in symptom onset between cultivars of the same crop. Similar to the results of

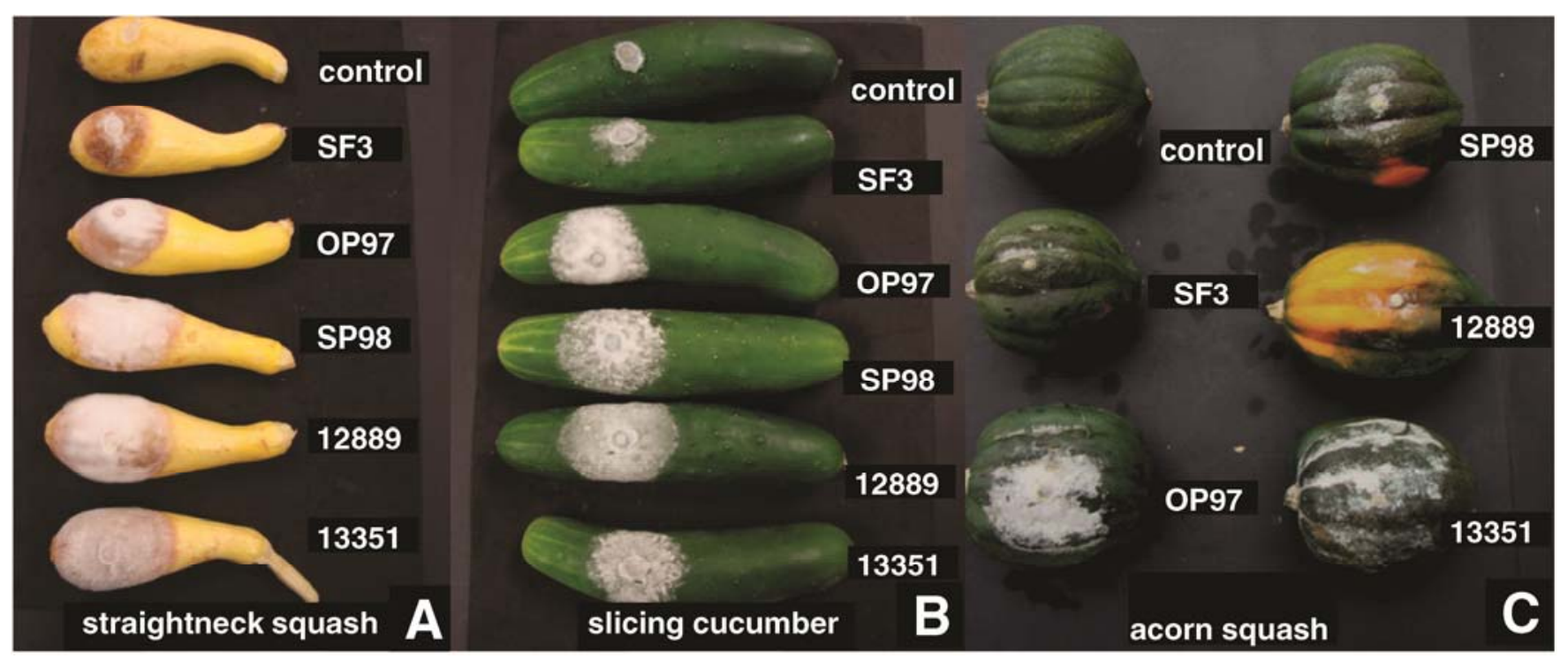

Fig. 4. A, Straightneck squash and B, slicing cucumber fruit 5 days post inoculation (dpi) and C, acorn squash fruit 8 dpi following inoculation with Phytophthora capsici isolates SF3, OP97, SP98, 12889, and 13351. Note differences in isolate virulence within fruit types. 
Camp et al. (5), there were no differences in disease severity between cultivars of the same crop with regards to straightneck squash. In this study, differences in AUDPC values between butternut squash and zucchini cultivars were observed following inocula-
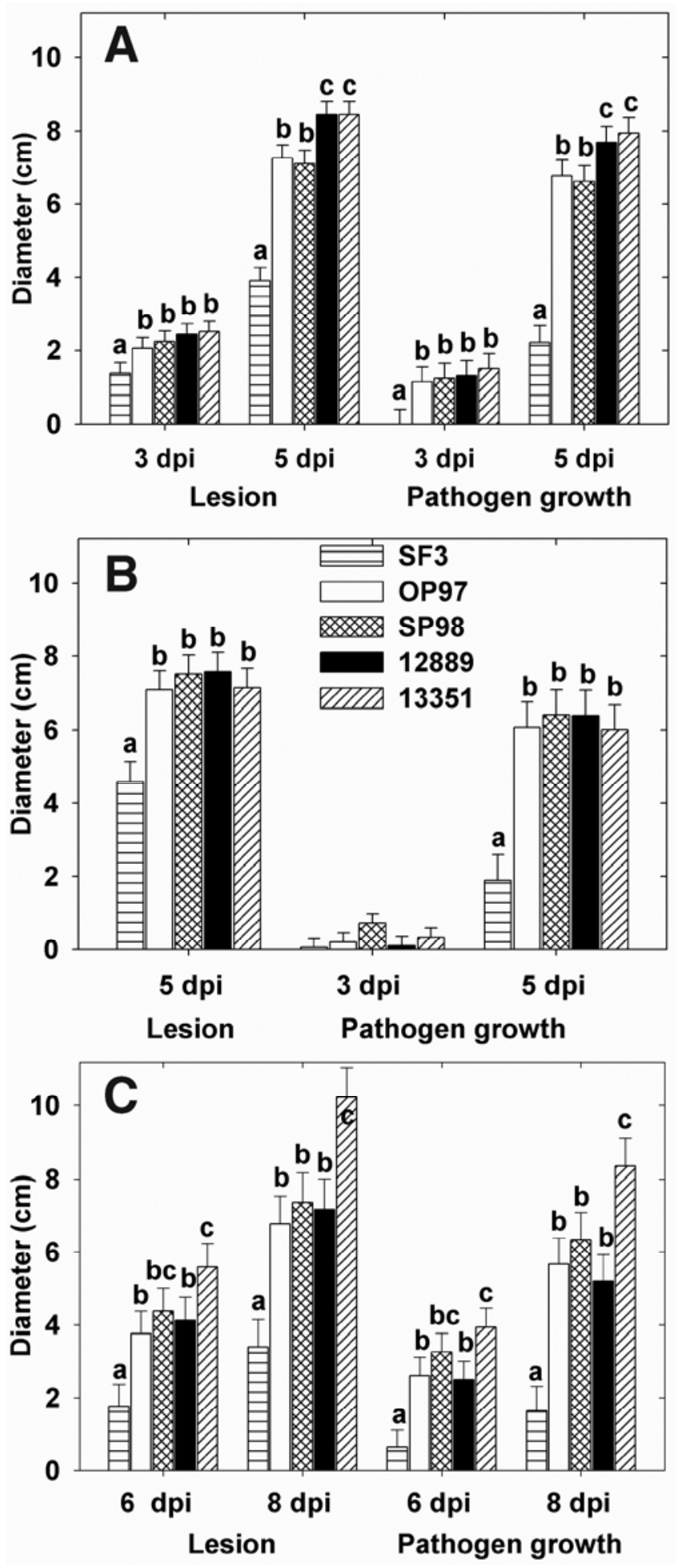

Fig. 5. Lesion and pathogen growth diameters observed on A, summer squash; $\mathbf{B}$, cucumber; and $\mathbf{C}$, winter squash fruit following inoculation with Phytophthora capsici isolates SF3, OP97, SP98, 12889, and 13351. Disease was evaluated 3 and 5 days post inoculation (dpi) in fruit experiment for summer squash and cucumber and 6 and 8 dpi for winter squash. Bars with a letter in common are not significantly different for each response variable within each dpi (Fisher's protected least significant difference, $P=0.05$ ). Bars represent + standard error. Disease was not observed on nor was $P$. capsici was recovered from control fruit, which were not included in data analyses. tions with isolate 13351. Overall, higher AUDPC values were attained by seedlings in experiment 1 compared with experiment 2 . Air temperature was similar for both experiments; however, relative humidity was higher during experiment 1 , which was conducted in summer, than for experiment 2 , which was conducted in winter. The survival of mycelia and sporangia in plant tissue has been shown to decrease with lower relative humidity (44). Granke and Hausbeck (19) found that isolate SP98 produced significantly more sporangia on fruit tissue at $60 \%$ relative humidity compared with a lower relative humidity (approximately 35\%). Hence, the lower relative humidity during experiment 2 may have impacted disease severity; nonetheless, relative humidity was still suitable for pathogen growth. Different cultivars were used in experiments 1 and 2, which also may have influenced AUDPC values.

Comparable results regarding differences in $P$. capsici isolate virulence have been observed in other studies. Variation in virulence of $P$. capsici has been noted in studies evaluating susceptibility of pepper fruit and plants $(14,36,41)$, tomato plants (40), and cucurbit fruit and plants $(26,38,48)$. However, Gevens et al. (17) did not find any differences in isolate (OP97, SF3, SFF3 [CT = A2, insensitive to mefenoxam], and SP98) virulence in initial cucumber fruit rot cultivar and cultigen (PI) studies and, accordingly, used one $P$. capsici isolate (OP97) for subsequent screenings. Results similar to those of Gevens et al. (17) were obtained by QuesadaOcampo et al. (37); they found no difference in $P$. capsici isolate (OP97, SFF3, SP98, and 12889) virulence on Fraser fir (Abies fraseri Pursh Poir.) saplings.

In studies by Foster and Hausbeck (14) and Quesada-Ocampo and Hausbeck (40), isolate 12889 was the most virulent. Isolate 12889 caused disease on commercially-marketed, $P$. capsici-resistant pepper 'Paladin' (Syngenta Seeds, Inc., Boise, ID) in Foster and Hausbeck's study (14). In this study, isolates 12889 and 13351 collected from solanaceous crops (pepper and eggplant, respectively) were most virulent on summer squash fruit. Likewise, isolate 13351 was the most virulent on winter squash fruit. In seedling experiment 1 , isolate 13351 was most virulent and, in experiment 2, straightneck squash cultivars inoculated with isolate SP98 (collected from pumpkin) had the highest AUDPC values, although statistically similar to those attained with isolates 12889 and 13351. Isolates SF3 and OP97, both collected from the cucurbitaceous host pickling cucumber, were less virulent on cucurbit fruit and seedlings than isolates collected from solanaceous hosts.

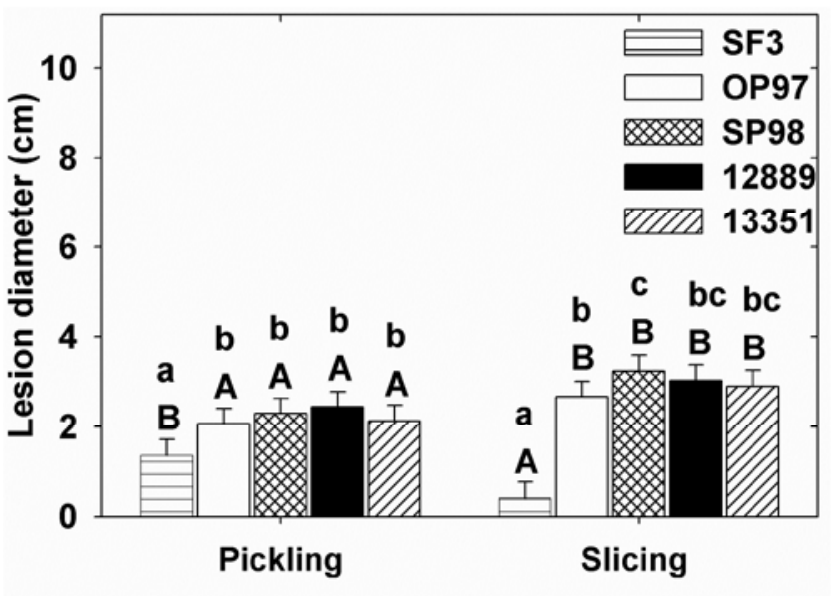

Cucumber fruit

Fig. 6. Lesion diameters observed on pickling and slicing cucumber fruit 3 days post inoculation following inoculation with Phytophthora capsici isolates SF3, OP97, SP98, 12889, and 13351. Bars with a letter in common are not significantly different within each fruit (lowercase) and among pathogen isolates (uppercase) (Fisher's protected least significant difference, $P=0.05$ ). Bars represent + standard error. Disease was not observed on nor was $P$. capsici was recovered from control fruit, which were not included in data analysis. 


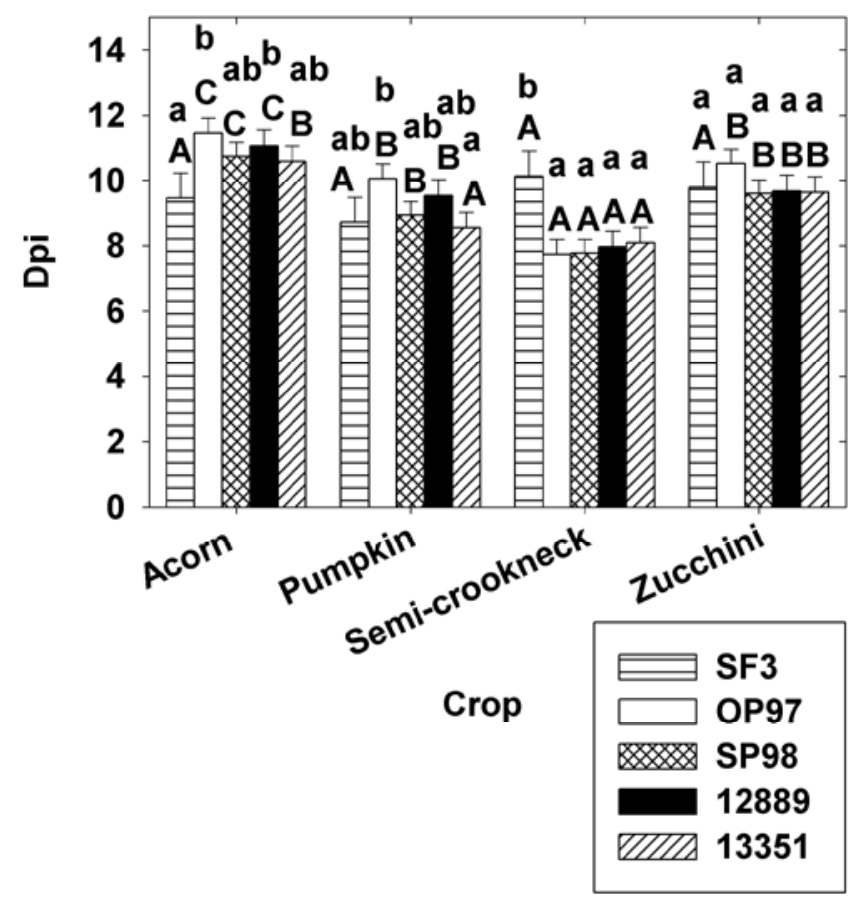

Fig. 7. Symptom appearance days post inoculation (dpi) of cucurbit seedlings (acorn squash, pumpkin, semi-crookneck squash, and zucchini) evaluated in experiment 1 for susceptibility to root and crown rot caused by Phytophthora capsici isolates SF3, OP97, SP98, 12889, and 13351. Bars with a letter in common are not significantly different within each crop (lowercase) and among pathogen isolates (uppercase) (Fisher's protected least significant difference, $P=0.05$ ). Bars represent + standard error. Disease was not observed on nor was $P$. capsici recovered from control seedlings, which were not included in data analysis.

Although isolates collected from solanaceous hosts were highly virulent on squash fruit and seedlings in this study and in the studies conducted by Foster and Hausbeck (14) and Quesada-Ocampo and Hausbeck (40), it is not conclusive that isolates recovered from solanaceous hosts are always more virulent on susceptible crops than isolates recovered from other hosts. Lee et al. (26) observed the converse in their study; isolates collected from pumpkin caused significantly greater disease on pumpkin than isolates collected from pepper. Isolate SP98, collected from pumpkin, was consistently virulent on fruit and seedlings in this study. Overall, the most virulent isolates on cucurbits in this study were those collected from solanaceous hosts, supporting the recommendation that eggplant, pepper, or tomato should not be included in crop rotations with cucurbits when Phytophthora rot is of concern.

No differences in susceptibility to root and crown rot were found between the straightneck squash cultivars evaluated in this study; however, Waltham butternut squash and Zucchini Elite zucchini seedlings exhibited reduced disease when compared with Butterbush butternut squash and Leopard zucchini, respectively. The amount of disease observed on Waltham butternut squash or Zucchini Elite zucchini when paired with isolates SP98, 12889, and 13351 would not be acceptable according to grower standards. However, if these cucurbits were paired with isolates SF3 or OP97, disease may not be as severe, and plants may survive to yield fruit, decreasing the likelihood of a total, devastating crop loss. Only two cultivars of butternut squash and zucchini were evaluated in this study; other experiments are necessary to ascertain whether there are less susceptible, commercially available cultivars that growers could incorporate into their production systems.

Germplasm screening by Chavez et al. (6) and Padley et al. (32) identified summer and winter squash lines that exhibit reduced crown rot. Resistance to crown rot derived from two wild species, C. lundelliana and C. okeechobeensis subsp. okeechobeensis, has been introgressed into the $C$. moschata breeding line number 3941-27-12 from the University of Florida (31). Crown rot resistance
Table 5. Area under the disease progress curve (AUDPC) values for experiment 1 evaluating cucurbit seedling susceptibility to root and crown rot caused by Phytophthora capsici isolates SF3, OP97, SP98, 12889, and $13351^{\mathrm{y}}$

\begin{tabular}{lclc}
\hline Crop $^{z}$ & AUDPC & $\begin{array}{c}\text { P. } \text { capsici } \\
\text { isolate }\end{array}$ & AUDPC \\
\hline Acorn squash & $15 \mathrm{ab}$ & SF3 & $8 \mathrm{a}$ \\
Pumpkin & $18 \mathrm{~b}$ & OP97 & $20 \mathrm{~b}$ \\
Semi-crookneck squash & $29 \mathrm{c}$ & SP98 & $23 \mathrm{~b}$ \\
Zucchini & $15 \mathrm{a}$ & 12889 & $22 \mathrm{~b}$ \\
& $\ldots$ & 13351 & $25 \mathrm{~b}$ \\
\hline
\end{tabular}

y AUDPC values were calculated by using disease severity ratings at 2-day intervals for 14 days post inoculation, where $0=$ no visible symptoms, $1=$ leaves slightly wilted, 2 = foliar wilting with crown lesion present at soil line, 3 = plant partially collapsed, $4=$ plant completely collapsed, and $5=$ death. Means within columns followed by the same letter are not significantly different (Fisher's protected least significant difference, $P=$ $0.05)$.

${ }^{\mathrm{z}}$ Disease was not observed on nor was $P$. capsici recovered from control seedlings, which were not included in data analysis.

was found to be controlled by three dominant genes, and it is unknown whether the foliar blight resistance that number 394-1-2712 also exhibits is conferred by the same mechanism (31). Varying levels of pepper resistance to the disease syndromes of root rot, stem blight, and foliar blight exist, and three different genetic mechanisms were found to be responsible for these separate disease syndromes $(3,47)$. Differences in this study were observed regarding pumpkin and other winter squash fruit rot compared with seedling root and crown rot. Future germplasm studies evaluating cucurbit cultivars and accessions to all diseases (root, crown, and fruit rot and foliar blight) would be worthwhile, not only to establish whether the same genetic mechanisms are involved for all disease symptoms and to discern whether they are separate syndromes but also for growers, so that they can be aware of which cultivars would work best in their production systems. In accordance with studies by Quesada-Ocampo et al. $(38,39)$, results from this study indicate that diverse isolates should be utilized in cucurbit germplasm screenings.

In the short term, cucurbit growers do not have options regarding resistant cultivars. With this limitation, Michigan growers may benefit from planting several desirable cultivars in a field, because one cultivar may be more tolerant to the local $P$. capsici isolates compared with other cultivars. An additional viable option may include growing a crop with reduced fruit susceptibility, such as zucchini compared with straightneck squash or spaghetti squash compared with butternut squash. Based on this study, growers can expect diseased yellow squash seedlings and summer squash fruit to exhibit symptoms before winter squash.

Disease did not develop uniformly on winter squash fruit without surface wounding (tested prior to experiments) in this study; disease occurred on only two pumpkin fruit without surface wounding prior to inoculation (tested prior to experiments; data not shown). Some cucurbit fruit have increased tolerance to $P$. capsici as they mature (1); however, age-related resistance is negated in cucumber fruit by surface wounding (19). The level of negation of age-related resistance by wounding in winter squash fruit is not known; hence, care should be taken to avoid superficial wounds during harvest and storage to decrease the potential of disease occurrence in winter squash.

\section{Acknowledgments}

This research is based upon work supported by the United States Department of Agriculture NIFA Special Research Grant Program under award number 2009-34572-19990 and the Pickle and Pepper Research Committee of MSU, Pickle Packers International, Inc. We thank Bartley Farms, MI, T. Superak of Harris Moran Seed Co., CA, and the Southwest Michigan Research and Extension Center, Benton Harbor, MI for fruit and seed donations; C. Smart for providing a pathogen isolate used in this research; A. Bloemers, A. Cortright, B. Cortright, A. Cook, S. Glaspie, T. VanderMaas, and B. Webster for technical assistance; S. Linderman and M. Meyer for document review; and K. Ananyeva and A. Worth for help with statistical analyses. 
Table 6. Area under the disease progress curve (AUDPC) values for experiment 2 evaluating cucurbit cultivar seedling susceptibility to root and crown rot caused by Phytophthora capsici isolates

\begin{tabular}{|c|c|c|c|c|c|}
\hline \multirow[b]{2}{*}{ Crop } & \multicolumn{5}{|c|}{ AUDPC for $P$. capsici isolates ${ }^{\mathrm{Z}}$} \\
\hline & SF3 & OP97 & SP98 & 12889 & 13351 \\
\hline \multicolumn{6}{|l|}{ Butternut squash } \\
\hline 'Butterbush' & $0 \mathrm{aA}$ & $7 \mathrm{bAB}$ & $19 \mathrm{cA}$ & $14 \mathrm{bcAB}$ & $20 \mathrm{cB}$ \\
\hline ‘Waltham' & $1 \mathrm{aA}$ & $3 \mathrm{aA}$ & $15 \mathrm{bA}$ & $10 \mathrm{bA}$ & $11 \mathrm{bA}$ \\
\hline \multicolumn{6}{|l|}{ Straightneck squash } \\
\hline 'Cougar' & $3 \mathrm{aA}$ & $17 \mathrm{bD}$ & $30 \mathrm{cB}$ & $25 \mathrm{cC}$ & $25 \mathrm{cC}$ \\
\hline 'Lioness' & $3 \mathrm{aA}$ & $17 \mathrm{bCD}$ & $27 \mathrm{cB}$ & $26 \mathrm{cC}$ & $23 \mathrm{bcBC}$ \\
\hline \multicolumn{6}{|l|}{ Zucchini } \\
\hline 'Leopard' & $1 \mathrm{aA}$ & $11 \mathrm{bBC}$ & $18 \mathrm{bcA}$ & $15 \mathrm{bcAB}$ & $20 \mathrm{cB}$ \\
\hline 'Zucchini Elite' & $3 \mathrm{aA}$ & $11 \mathrm{bB}$ & $17 \mathrm{bA}$ & $16 \mathrm{bB}$ & $15 \mathrm{bA}$ \\
\hline
\end{tabular}

${ }^{2}$ AUDPC values were calculated by using disease severity ratings at 2 -day intervals for 14 days post inoculation, where $0=$ no visible symptoms, $1=$ leaves slightly wilted, $2=$ foliar wilting with crown lesion present at soil line, $3=$ plant partially collapsed, $4=$ plant completely collapsed, and $5=$ death. Disease was not observed on nor was P. capsici recovered from control seedlings, which were not included in data analysis. Means within rows followed by the same lowercase letter are not significantly different within each cultivar, and means within columns followed by the same uppercase letter are not significantly different within each pathogen isolate (Fisher's protected least significant difference, $P=0.05$ ).

\section{Literature Cited}

1. Ando, K., Hammar, S., and Grumet, R. 2009. Age-related resistance of diverse cucurbit fruit to infection by Phytophthora capsici. J. Am. Soc. Hortic. Sci. 134:176-182.

2. Babadoost, M. 2004. Phytophthora blight: a serious threat to cucurbit industries. APSnet Feature Story. Online publication. http://www.apsnet.org/ publications/apsnetfeatures/Pages/PhytophthoraBlight.aspx

3. Barksdale, T. H., Papavizas, G. C., and Johnston, S. A. 1984. Resistance to foliar blight and crown rot of pepper caused by Phytophthora capsici. Plant Dis. 68:506-509.

4. Café-Filho, A. C., Duniway, J. M., and Davis, R. M. 1995. Effects of the frequency of furrow irrigation on root and fruit rots of squash caused by Phytophthora capsici. Plant Dis. 79:44-48.

5. Camp, A. R., Lange, H. W., Reiners, S., Dillard, H. R., and Smart, C. D. 2009. Tolerance of summer and winter squash lines to Phytophthora blight, 2008. Plant Dis. Manage. Rep. 3:V022. Online publication. doi:10.1094/PDMR03

6. Chavez, D. J., Kabelka, E. A., and Chaparro, J. X. 2011. Screening of Cucurbita moschata Duchesne germplasm for crown rot resistance to Floridian isolates of Phytophthora capsici Leonian. HortScience 46:536540.

7. Crossan, D. F., Hassis, F. A., and Ellis, D. E. 1954. Phytophthora blight of summer squash. Plant Dis. Rep. 38:557-559.

8. Davey, J. F., Gregory, N. F., Mulrooney, R. P., Evans, T. A., and Carroll, R. B. 2008. First report of mefenoxam-resistant isolates of Phytophthora capsici from lima bean pods in the Mid-Atlantic region. Plant Dis. 92:656.

9. Davidson, C. R., Carroll, R. B., Evans, T. A., and Mulrooney, R. P. 2002. First report of Phytophthora capsici infecting lima bean (Phaseolus luna$t u s)$ in the Mid-Atlantic region. Plant Dis. 86:1049.

10. Drechsler, C. 1929. A fruit rot of honey dew melons due to a species of Phytophthora. (Abstr.) Phytopathology 19:85.

11. Dunn, A. R., Milgroom, M. G., McLeod, A., Fry, W. E., McGrath, M. T., Dillard, H. R., and Smart, C. D. 2010. Population structure and resistance to mefenoxam of Phytophthora capsici in New York State. Plant Dis. 94:14611468.

12. Erwin, D. C., and Ribeiro, O. K. 1996. Phytophthora Diseases Worldwide. American Phytopathological Society, St. Paul, MN.

13. Farr, D. F., and Rossman, A. Y. Fungal Databases, Systemic Mycology and Microbiology Laboratory, ARS, USDA. http://nt.ars-grin.gov/fungal databases/

14. Foster, J. M., and Hausbeck, M. K. 2010. Resistance of pepper to Phytophthora crown, root, and fruit rot is affected by isolate virulence. Plant Dis. 94:24-30.

15. Gevens, A. J., Donahoo, R. S., Lamour, K. H., and Hausbeck, M. K. 2007. Characterization of Phytophthora capsici from Michigan surface irrigation water. Phytopathology 97:421-428.

16. Gevens, A. J., Donahoo, R. S., Lamour, K. H., and Hausbeck, M. K. 2008. Characterization of Phytophthora capsici causing foliar and pod blight of snap bean in Michigan. Plant Dis. 92:201-209.

17. Gevens, A. J., Lamour, K. H., Grument, R., and Hausbeck, M. K. 2006. A detached cucumber fruit method to screen for resistance to Phytophthora capsici and effect of fruit age on susceptibility to infection. Plant Dis. 90:1276-1282

18. Granke, L. L., and Hausbeck, M. K. 2010. Effects of temperature, concentration, age, and algaecides on Phytophthora capsici zoospore infectivity. Plant Dis. 94:54-60.

19. Granke, L. L., and Hausbeck, M. K. 2010. Effects of temperature, humidity, and wounding on development of Phytophthora rot of cucumber fruit. Plant Dis. $94: 1417-1424$
20. Granke, L. L., Windstam, H. C., Smart, C. D., and Hausbeck, M. K. 2009. Dispersal and movement mechanisms of Phytophthora capsici sporangia Phytopathology 99:1258-1264.

21. Hausbeck, M. K., and Lamour, K. H. 2004. Phytophthora capsici on vegetable crops: research progress and management challenges. Plant Dis. 88:1292-1303.

22. Kim, E. S., and Hwang, B. K. 1992. Virulence to Korean pepper cultivars of isolates of Phytophthora capsici from different geographic areas. Plant Dis. 76:486-489.

23. Kreutzer, W. A. 1937. A Phytophthora rot of cucumber fruit. (Abstr.) Phytopathology 27:955.

24. Kreutzer, W. A., Bodine, E. W., and Durrell, L. W. 1940. Cucurbit diseases and rot of tomato fruit caused by Phytophthora capsici. Phytopathology 30:972-976.

25. Lamour, K. H., and Hausbeck, M. K. 2000. Mefenoxam insensitivity and the sexual stage of Phytophthora capsici in Michigan cucurbit fields. Phytopathology 90:396-400.

26. Lee, B. K., Kim, B. S., Chang, S. W., and Hwang, B. K. 2001. Aggressiveness to pumpkin cultivars of isolates of Phytophthora capsici from pumpkin and pepper. Plant Dis. 85:497-500.

27. Leonian, L. H. 1922. Stem and fruit blight of peppers caused by Phytophthora capsici sp. nov. Phytopathology 12:401-408.

28. Mathis, W. L., Williams-Woodward, J., and Csinos, A. S. 1999. Insensitivity of Phytophthora capsici to mefenoxam in Georgia. (Abstr.) Phytopathology 89:S49.

29. McCullagh, P. 1980. Regression models for ordinal data. J. R. Stat. Soc. Ser. B (Methodological) 42:109-142.

30. Ngouajio, M., Wang, G., and Hausbeck, M. K. 2006. Changes in pickling cucumber yield and economic value in response to planting density. Crop Sci. 46:1570-1575.

31. Padley, L. D., Jr., Kabelka, E. A., and Roberts, P. 2009. Inheritance of resistance to crown rot caused by Phytophthora capsici in Cucurbita. HortScience 44:211-213.

32. Padley, L. D., Jr., Kabelka, E. A., Roberts, P., and French, R. 2008. Evaluation of Cucurbita pepo accessions for crown rot resistance to isolates of Phytophthora capsici. HortScience 43:1996-1999.

33. Parra, G., and Ristaino, J. 1998. Insensitivity to Ridomil Gold (mefenoxam) found among isolates of Phytophthora capsici causing Phytophthora blight on bell pepper in North Carolina and New Jersey. Plant Dis. 82:711.

34. Parra, G., and Ristaino, J. B. 2001. Resistance to mefenoxam and metalaxyl among field isolates of Phytophthora capsici causing Phytophthora blight of pepper. Plant Dis. 85:1069-1075.

35. Pennisi, A. M., Agosteo, G. E., Cacciola, S. O., Pane, A., and Faedda, R. 1998. Insensitivity to metalaxyl among isolates of Phytophthora capsici causing root and crown rot of pepper in southern Italy. Plant Dis. 82:1283.

36. Polach, F. J., and Webster, R. K. 1972. Identification of strains and inheritance of pathogenicity in Phytophthora capsici. Phytopathology 62:20-26.

37. Quesada-Ocampo, L. M., Fulbright, D. W., and Hausbeck, M. K. 2009. Susceptibility of Fraser fir to Phytophthora capsici. Plant Dis. 93:135-141.

38. Quesada-Ocampo, L. M., Granke, L. L., and Hausbeck, M. K. 2010. Differences in virulence of Phytophthora capsici isolates from a worldwide collection on zucchini fruit. Pages 248-251 in: Cucurbitaceae 2010 Proc. Am. Soc. Hortic. Sci. Charleston, SC.

39. Quesada-Ocampo, L. M., Granke, L. L., Mercier, M. R., Olsen, J., and Hausbeck, M. K. 2011. Investigating the genetic structure of Phytophthora capsici populations. Phytopathology 101:1061-1073.

40. Quesada-Ocampo, L. M., and Hausbeck, M. K. 2010. Resistance in tomato and wild relatives to crown and root rot caused by Phytophthora capsici. Phytopathology 100:619-627.

41. Ristaino, J. B. 1990. Intraspecific variation among isolates of Phytophthora 
capsici from pepper and squash in North Carolina. Phytopathology 80:1253-1259.

42. Ristaino, J. B. 1991. Influence of rainfall, drip irrigation, and inoculum density on the development of Phytophthora root and crown rot epidemics and yield in bell pepper. Phytopathology 81:922-929.

43. Ristaino, J. B., and Johnston, S. A. 1999. Ecologically based approaches to management of Phytophthora blight on bell pepper. Plant Dis. 83:10801088.

44. Schlub, R. L. 1983. Epidemiology of Phytophthora capsici on bell pepper. J. Agric. Sci. 100:7-11.

45. Shaner, G., and Finney, R. E. 1977. The effect of nitrogen fertilization on the expression of slow-mildewing resistance in Knox wheat. Phytopathology 67:1051-1056.

46. Silvar, C., Merino, F., and Diaz, J. 2006. Diversity of Phytophthora capsici in Northwest Spain: analysis of virulence, metalaxyl response, and molecu- lar characterization. Plant Dis. 90:1135-1142.

47. Sy, O., Bosland, P. W., and Steiner, R. 2005. Inheritance of Phytophthora stem blight resistance as compared to Phytophthora root rot and Phy tophthora foliar blight resistance in Capsicum annuum L. J. Am. Soc. Hortic. Sci. 130:75-78

48. Tian, D., and Babadoost, M. 2004. Host range of Phytophthora capsici from pumpkin and pathogenicity of isolates. Plant Dis. 88:485-489.

49. Tompkins, C. M., and Tucker, C. M. 1941. Root rot of pepper and pumpkin caused by Phytophthora capsici. J. Agric. Res. 63:417-427.

50. United States Department of Agriculture (USDA), National Agriculture Statistics Service (NASS). 2011. Vegetables 2010 Annual Summary. Online publication. http://usda01.library.cornell.edu/usda/nass/VegeSumm//2010s/ 2011/VegeSumm-01-27-2011.pdf

51. Waterhouse, G. M. 1963. Key to the Species of Phytophthora de Bary. The Commonwealth Mycological Society, Kew, Surrey, UK. 